$\mathrm{A} \int_{\text {ass }} \mathrm{H}$

Received : 29.01.2015

Revised : 02.04.2015

Accepted : 03.05.2015

Members of the Research Forum

Associated Authors:

${ }^{1}$ Directorate of Research, Dr. Y.S.R.

Horticultural University,

Rajendranagar, HYDERABAD

(TELANGANA) INDIA

Email : jampaladilip@gmail.com
Author for correspondence :

\section{T. BABY RANI}

Floricultural Research Station, Dr.

Y.S.R. Horticultural University,

Rajendranagar, HYDERABAD

(TELANGANA) INDIA

Email : ranikalapala2311@

gmail.com
THEASIAN JOURNAL OF HORTICULTURE

Volume 10 | Issue 1 | June, 2015 | 80-85

Visit us -www.researchjournal.co.in

\title{
Acceptability and storage studies of guava - Aloe nectar blends
}

\section{T. BABY RANI AND J. DILIP BABU ${ }^{1}$}

ABSTRACT : A study was undertaken during 2011 at post harvest technology laboratory, College of Horticulture, Rajendranagar, Hyderabad, to prepare value added products from guava blended with Aloe vera and assess their storage behaviour and acceptability. By following a standardized protocol, nectar blends of guava and aloe were prepared. Pulps were extracted separately, blended at desired proportions, homogenized and used for making nectar blends. Products were preserved by pasteurization and packed in $200 \mathrm{ml}$ glass bottles. In order to study storage stability and consumer acceptability, products were stored for a period of three months at $10+10^{\circ} \mathrm{C}$ and analyzed for physico chemical quality and overall acceptability at monthly intervals. Results depict that there was slight increase in total soluble solids and acidity, and a considerable increase in reducing sugars but, slight decrease in $\mathrm{pH}$, total sugars and a considerable decrease in ascorbic acid and antioxidant activity during storage of 90 days. All the blends were acceptable at all the storage intervals. However, blending G:A at 70:30 was found highly acceptable with higher sensory score. In any blend, as the storage period increased, ascorbic acid and antioxidant activity declined but there was minimum decrease noticed in G:A at 60:40 which was found more shelf stable.

KEY WORDS : Aloe, Ascorbic acid, Guava, Storage studies, Total anti-oxidant activity, Per cent TBARS, Per cent inhibition of peroxidation

HOW TO CITE THIS ARTICLE : Rani, T. Baby and Babu, J. Dilip (2015). Acceptability and storage studies of guava - Aloe nectar blends. Asian J. Hort., 10(1) : 80-85. 